\title{
The Role of Foreign Assistance Programs in the Development of Exportable Horticultural Crops
}

\author{
Howard L. Steele \\ Office of International Cooperation and Development, United States Department of Agriculture, \\ Washington, DC 20523
}

It is from experiences during 8 years of working as a project manager in various United States Agency for International Development (USAID) Missions overseas, principally in Latin American countries, and since 1984 within the Latin American and Caribbean Bureau of USAID in Washington, D.C. that these remarks are made. I have worked with various indigenous groups in Guatemala, Bolivia, Honduras, and Belize as they attempted to diversify their agricultural production base. That diversification usually, but not always, means moving from production for export of traditional commodities, such as sugar, bananas, and coffee, to high-value horticultural crops, such as temperate and tropical fruits and vegetables.

Most of this activity has been promoted by host country governments, USAID missions, and other bilateral and multinational organizations because of the realization that world supplies and prices for many of the traditional export commodities had become problematic. Over supplies of sugar, coffee, and bananas, and chronic softening of world prices coupled with growing debt burdens and a dearth of foreign exchange reserves, were catalytic in leading developing country leaders to want to diversify their agricultural production/marketing bases. In the Americas, the movement accelerated rapidly with passage of the Caribbean Basin Economic Recovery Act (U.S. Congress, 1983) in Aug. 1983.

\section{THE CARIBBEAN BASIN INITIATIVE (CBI)}

The Caribbean Basin Economic Recovery Act established a oneway free trade proposal between the United States and some 27 developing countries in Central America and the Caribbean islands (Table 1). The legislation was in response to bipartisan concern in the United States, also expressed in Mexico, Canada, Colombia, and Venezuela, that the economic crises in the CBI region would soon lead to additional and serious political instabilities if not corrected.

The legislation passed by Congress is to be in effect until 1996 and is designed to promote economic revitalization in the region by waiving prevailing duties on most products imported into the United

Opinions expressed and conclusions drawn are solely mine. Neither the Office of International Cooperation and Development nor any other agency of the United States Government is responsible in anyway for these remarks. Any errors made are also my responsibility. Thanks to Larry Boone and Richard Brown, Economic Research Service/USDA; Tom King, Rural Development Division/USAID's Bureau for Latin America and the Caribbean; and to three anonymous HortScience reviewers for their valuable suggestions and assistance. L. George Wilson, North Carolina State Univ., gave helpful encouragement and suggestions. Thanks to Allison Farwell, USAID's Bureau for Latin America and the Caribbean, for typing many drafts.

'Present address: Agency for International Development, Washington, DC 20523.
States from these designated beneficiary CBI countries. The basic provisions of the Act (U.S. Congress, 1983) include the following: a) Duty-free imports on eligible articles; b) designation of beneficiary countries; c) list of exempt commodities; d) rule-of-origin requirements; and e) procedures to provide emergency relief from imports.

The Act exempted certain commodities from duty free status. Included were textiles and apparel; footware, handbags, luggage, flat goods, work gloves, and leather wearing apparel; canned tuna; petroleum and petroleum products; watches and watch parts; and limitations on duty-free entry of sugar. In the latter case, the president has imposed sugar quotas based on each country's historical share of the market.

The rule of origin requirement was designed to assure that an article of commerce under the Act is produced in the designated CBI country to qualify for duty-free treatment. The provisions seek to prohibit "pass through" operations and "runaway plants". Dutyfree status may be accorded an article or commodity only if the sum of the cost or value of the material produced in a beneficiary country or countries, plus the direct costs of processing operations, is not $<3570$ of the appraised value of the article at the time it is entered.

Under the import and emergency relief provisions of the Act, a special procedure is established to protect American producers of perishable agricultural products. If they file an import relief petition (with the Dept. of Commerce under the Trade Act of 1974), they may also file a request with the secretary of agriculture for emergency relief. Upon recommendation from the secretary of agricultture, following 14 days of investigation of the extent of injury to American producers, the president can withdraw duty-free treatment. Perishable products are defined in the Act as live plants, most

Table 1. Designated CBI countries, as specified in the Caribbean Basin Economic Recovery Act of Aug. 1983.

\begin{tabular}{ll}
\hline \hline & Potential beneficiary countries \\
\hline Anguilla & British Virgin Islands \\
Antigua and Barbuda & Jamaica \\
The Bahamas & Nicaragua \\
Barbados & Panama \\
Belize & St. Lucia \\
Costa Rica & St. Vincent and the Grenadines \\
Dominica & Suriname \\
Dominican Republic & Trinidad and Tobago \\
El Salvador & Cayman Islands \\
Grenada & Montserrat \\
Guatemala & Netherlands Antilles \\
Guyana & (including Aruba) \\
Haiti & St. Christopher-Nevis \\
Honduras & Turks and Caicos Islands \\
\hline
\end{tabular}


Table 2. U.S. imports of selected agricultural products from Central America and the Caribbean.

\begin{tabular}{|c|c|c|c|c|c|c|c|c|}
\hline \multirow[b]{2}{*}{ Product } & \multicolumn{8}{|c|}{ Calendar year imports for } \\
\hline & 1979 & 1980 & 1981 & 1982 & 1983 & 1984 & 1985 & 1986 \\
\hline & \multicolumn{8}{|c|}{ U.S. dollars (millions) } \\
\hline Total $^{y}$ & 2085 & 2136 & 1865 & 1535 & 1755 & 1918 & 1814 & 2131 \\
\hline Traditional items & 1985 & 2039 & 1745 & 1418 & 1617 & 1739 & 1617 & 1916 \\
\hline Coffee & 890 & 739 & 433 & 506 & 524 & 599 & 645 & 1005 \\
\hline Bananas & 268 & 292 & 360 & 363 & 392 & 400 & 451 & 419 \\
\hline Sugar & 335 & 657 & 636 & 264 & 425 & 429 & 265 & 220 \\
\hline Beef and veal, frozen & 308 & 226 & 183 & 165 & 133 & 100 & 118 & 131 \\
\hline Molasses & 33 & 31 & 47 & 23 & 29 & 40 & 18 & 24 \\
\hline Cocoa & 126 & 76 & 65 & 68 & 65 & 99 & 84 & 88 \\
\hline Tobacco & 25 & 18 & 20 & 29 & 49 & 72 & 36 & 29 \\
\hline Nontraditional items & 100 & 97 & 120 & 117 & 138 & 179 & 197 & 215 \\
\hline
\end{tabular}

${ }^{2}$ Source: "Western Hemisphere Situation and Outlook Report", Washington, D. C., July 1987, USDA Econ. Res. Serv., RS-87-7, p. 30.

A simple summation of official U.S. agricultural imports from the Caribbean and Central American regions provides a close approximation of U.S. agricultural imports from CBI countries.

fresh or chilled vegetables, fresh mushrooms, most fresh fruit, fresh cut flowers, and concentrated citrus fruit juices.

\section{USAID PROGRAM AND PROJECT INITIATIVES UNDER CBI}

USAID missions in the region were quick to plan and implement projects with their host country counterparts, projects that would take advantage of the provisions of the CBI program, as were other bilateral assistance and multinational agencies. Many of the USAID missions had been concerned with methods to help host countries diversify out of monoculture for several years before the Kissinger and Jackson Commission made their recommendations. Many USAID concepts and suggestions were incorporated in the Kissinger and Jackson reports.

The various USAID mission projects carry diverse designations, although a common feature of each is to key to the possibility of eventually exporting more commodities to United States, Canadian, or European markets. However, it is sometimes hard to determine exactly how much of a given USAID project is truly dedicated to promoting export development, since many of the subproject activities are really focused on helping small farmers diversify out of monoculture, such as the production of corn or beans season after season, and into higher-value crops using more advanced levels of technology for the domestic markets of their country.

\section{THE EXPANDING UNITED STATES MARKET FOR HORTICULTURAL PRODUCTS}

The United States imported nearly \$6.6 billion of horticultural products into the country in 1986 . Of this amount, about $\$ 215$ million, classified as "non-traditional", came from the $27 \mathrm{CBI}$ countries (Table 2). Horticultural products made up $74 \%$ of the "non-traditionals", with a 1986 value of $\$ 159.2$ million (Table 3). In fact, importation of horticultural commodities into the U.S. on a weight-of-product basis is now dominated by Mexico, which accounts for an average of $58 \%$ of all imports, excluding bananas and plantains (Table 4). Mexico dominates as the country of origin for many of the commodities of horticultural interest. Mexican imports represent $90 \%$ or more of the total for such horticultural imports as beans, broccoli, cucumbers, eggplant, okra, peppers, radishes, squash, tomatoes, and watermelons.

An analysis of USAID shows that only $0.5 \%$ of all horticultural imports into the United States were associated with USAID activities in the 17 CBI countries where AID had missions in 1985. The commodities had a value of about $\$ 30$ million. The important point is that the trend in horticultural exports from the CBI countries is a rapidly growing one (Brown, 1987), and it will continue unabated regardless of USAID'S efforts. The latest statistics show that nontraditional horticultural imports from these 27 countries have nearly doubled since the CBI was started in 1983; yet, they represent $<3.25 \%$ of total U.S. horticultural imports. Furthermore, the trend began long before the CBI legislation was conceived.

This growing business volume is important to the small CBI countries, however, and can mean the difference between economic collapse and economic health in the future. There are two logical reasons why this trend will continue: 1) Land values in the southeast continue to rise with the continued population growth in the area and land in agricultural production enterprises is being sold for nonagricultural development; and 2) the cost of wage labor employed in agriculture also continues to increase; locating sufficient quantities at crucial times when required is becoming more difficult. Countries in the Caribbean Basin are turning these factors to their advantage in attempting to attract additional entrepreneurial talent and capital to their shores.

\section{KINDS OF HELP USAID PROVIDES TO LDCs}

Nearly all of the USAID projects described above contain the following components: technical assistance, training, loan funds and equity capital promotion, and mechanisms for policy dialogue with host country governments regarding factors hindering improved economic development:

a) Technical assistance usually includes expatriate experts or specialists. These experts may be residents or short-term consultants brought to the country to achieve specific objectives. Often, they evaluate the feasibility of some contemplated action in the original USAID project concept, and/or follow up on its implementation. They also may serve as monitors of host country activities and identify successes and problems during various phases of the project's implementation. They serve as "hands-on" trainers in their areas of expertise, especially until an experienced cadre of indigenous personnel can be developed through training.

b) Training includes several types in most USAID projects: 1) long-term, academic training for a limited number of persons showing leadership potential; 2) short-term, specialized training of mid-level managers and operators of all types; 3 ) short-time observational/visitation trips for technicians and operations personnel; 4) in-country workshops and seminars organized by expatriat experts familiar with the technical problems confronted by personnel in the project, with heavy inputs by indigenous personnel; and 5) hands-on training on a one-on-one basis by expatriate specialists brought into long-term residence assignments by the project for that purpose.

c) Loan funds usually are passed by USAID through host country governments to be reloaned through the developing country's central, commercial, or development banking system at commercial rates of interest to project institutions. There is a great deal of misunderstanding about this process in the United States. No private sector firm in a developing country gets "cheap U.S. government credit" to engage in USAID export development activities. Agribusiness firms pay commercial or the going (current) interest rate in the developing country. Grant funds maybe given by USAID to provide expert U.S. technical assistance to a marketing cooperative to improve operational efficiency. Other USAID loans funds are provided to host country governments to improve their agricultural research and experiment stations, their 
Table 3. U.S. imports of horticultural and other agricultural products from Central America and the Caribbean, 1986.

\begin{tabular}{|c|c|c|}
\hline \multirow[b]{2}{*}{ Commodity } & \multicolumn{2}{|c|}{ U.S. dollars (thousands) } \\
\hline & Individual items & Totals \\
\hline Fruits, fresh or frozen & & 42,672 \\
\hline Strawberries & 331 & \\
\hline Apples & 150 & \\
\hline Citrus & 2,299 & - \\
\hline Mangoes & 3,763 & \\
\hline Melons & 17,820 & \\
\hline Pineapple & 18,036 & \\
\hline Others & 273 & \\
\hline Fruits, prepared or preserved & & 7,702 \\
\hline Pineapple & 260 & \\
\hline Others & 7,442 & \\
\hline Orange juice & & 8,611 \\
\hline Other fruit juices & & 7,815 \\
\hline Nuts and nut preparations & & \\
\hline Cashews & 587 & \\
\hline Coconut & 3,064 & \\
\hline Macademia & 1,741 & \\
\hline Others & 2,848 & \\
\hline Vegetables, fresh or frozen & & 50,636 \\
\hline Tomatoes & 2,758 & \\
\hline Asparagus & 51 & \\
\hline Beans & 131 & \\
\hline Cucumbers & 1,478 & \\
\hline Eggplant & 231 & \\
\hline Garlic & 135 & \\
\hline Onions & 115 & \\
\hline Onions & 6,708 & \\
\hline Peppers & 3,300 & \\
\hline Squash. & 709 & - \\
\hline Others & 35,020 & \\
\hline Vegetables, prepared or preserved & & 10,190 \\
\hline $\begin{array}{l}\text { Tomatoes, including } \\
\text { paste and sauce }\end{array}$ & 429 & \\
\hline Beans and peas, dried & 109 & \\
\hline Others & 9,652 & \\
\hline Seeds & & 6,037 \\
\hline Cut flowers & & 6,738 \\
\hline Nursery stock bulbs, etc. & & $\underline{10,551}$ \\
\hline Subtotal ("horticultural") & & $1 \overline{159,192}$ \\
\hline Other products & & 57,301 \\
\hline Tea- & 589 & \\
\hline Spices & 3,643 & \\
\hline Rubber & 874 & \\
\hline Other & 52,195 & \\
\hline Subtotal ("non-traditional") & & 216,493 \\
\hline Bananas and plantains & & 419,015 \\
\hline Coffee & & $1,005,394$ \\
\hline Cocoa & & 86,450 \\
\hline Beef and veal & & 130,890 \\
\hline Tobacco & & 28,874 \\
\hline Sugar, cane and beet & & 219,755 \\
\hline Molasses & & 23,930 \\
\hline Subtotal (“traditional”) & & $1,9 \overline{14,308}$ \\
\hline Total & & $\overline{2,130,762}$ \\
\hline
\end{tabular}

extension systems, and their agricultural technical schools and colleges. USAID also helps host country businesses get in touch with U.S. agribusiness entrepreneurs, possible joint capital venture partners, etc.

d) Policy dialogue uses certain types of economic support funds (such as food assistance provided by U.S. surplus commodity programs under Public Law 480) as leverage to convince governments to relax trade barriers, reduce subsidies or levies, such as export and import taxes, etc.

Finally, USAID supports many ancillary activities such as the Latin America and Caribbean Bureau's recent funding as partial support to reopen and operate USDA's Florida Fruit and Vegetable Market News office in Miami.

\section{RESTRICTIONS IMPOSED ON USAID}

The serious problems facing agriculture in the United States in the most recent 5-year period (especially loss of export markets for coarse grains, agricultural credit and finance difficulties in our midwest, and the strong dollar in overseas countries) led to lobbying efforts in our Congress to give U.S. farmers "relief from cheap imports". Horticultural imports from the CBI countries (Polopolus, 1985 ) and USAID's diversification and development efforts were questioned (U.S. Congress, 1986b)

USAID Policy Determination 15. This policy was issued by the Administrator of USAID on 13 Sept. 1986, partially in response to the Bumpers Amendment to the Supplemental Appropriations Act of "Congress of 2 July 1986 (U.S. Congress, 1986a). In effect, it says that USAID will avoid supporting the production of agricultural commodities for export by developing countries when the commodities would directly compete with exports of similar U.S. agricultural commodities to third countries and would cause "substantial injury" to U.S. exporters of the same or similar commodities. The Administrator's Determination directs USAID missions to examine the export dimension of on-going and proposed projects to evaluate if they may cause substantial injury to U.S. producers.

USAID Policy Determination 71. This AID administrator's policy was published on 12 May 1978 (USAID, 1978). In part, it says that "USAID should only finance projects when their development rationale is strong and their likely impact on U.S. producers is low". The policy discourages USAID from funding production, processing, or marketing projects involving sugar, palm oil, or citrus for export from LDCs. Multinational and other binational development agencies do not have the same kinds of commodity restrictions placed on their assistance activities with host countries as does USAID (Houck, 1987).

\section{TYPES OF HORTICULTURAL COMMODITIES SHOWING GROWTH POTENTLAL}

There are several different types of demand changes that I see taking place in North America and in western Europe that bode well for horticultural crop producers, wholesalers, and retailers in the near and intermediate future, Significant changes are taking place in the diets of most North Americans and western Europeans; the trend is to consume more fresh and frozen fruits and vegetables per capita per year (Table 5). United States per capita consumption of fresh fruits has increased from $34.9 \mathrm{~kg}$ in 1969 to $43 \mathrm{~kg}$ in 1985. Similarly, fresh vegetable consumption per capita has increased from $57.8 \mathrm{~kg}$ in 1969 to $75.5 \mathrm{~kg}$ in 1985 . Consumption of canned and dried fruits and vegetables has declined, as has intake of several livestock products, including beef, pork, some dairy products, eggs, and some saturated vegetable fats. (Annual per capita consumption of meat has decreased from $73.5 \mathrm{~kg}$ in 1968 to $65.3 \mathrm{~kg}$ in 1985; animal fat consumption decreased from $8.0 \mathrm{~kg}$ to $3.0 \mathrm{~kg}$, and egg consumption from ' $18.2 \mathrm{~kg}$ to $14.7 \mathrm{~kg}$.) These-trends are very positive for the horticultural products industry; there are some serious complications, however. Consumers want their fruits and vegetables fresh, year-round, at competitive prices, and at all retailers where they shop. The following different types of horticultural commodities are the major growth items. Each type requires specific marketing strategies:

a) Narrow windows of opportunity exist for providing fresh temperate-region fruit and vegetables to North America and western Europe in winter from the high valleys of countries such as Guatemala, Honduras, Costa Rica, and the Dominican Republic when U.S. producers cannot supply enough to meet demand. Prices are volatile, however, and transportation and handling from CBI countries are extremely difficult and cost half or more of the landed value. The following commodities are common items in the consumers' diets: peas, snap beans, cucumbers, tomatoes, strawberries, onions, apples, cauliflower, broccoli, and others.

b) Tropical and semi-tropical fruits and vegetables that make up a new component of North American and western European consumers' diets are growing in popularity because of the mer- 
Table 4. Share of U.S. fresh fruit and vegetable imports from Mexico and all other sources, 50 most important commodities, by weight, 1986 .

\begin{tabular}{|c|c|c|c|}
\hline Commodity & $\begin{array}{l}\text { Total imports from } \\
\text { all sources } \\
(\mathrm{t} ; 1000 \mathrm{~s})\end{array}$ & $\begin{array}{c}\text { Imports from } \\
\text { Mexico } \\
(\mathrm{t} ; 1000 \mathrm{~s}) \\
\end{array}$ & $\begin{array}{l}\text { Mexico imports } \\
\text { (\% of total) }\end{array}$ \\
\hline Peppers, chili & 27 & 27 & 98.3 \\
\hline Tomatoes & 445 & 431 & 96.8 \\
\hline Squash & 57 & 55 & 96.2 \\
\hline Broccoli & 4 & 4 & 94.8 \\
\hline Cucumbers & 195 & 185 & 94.8 \\
\hline Radishes & 9 & 9 & 94.6 \\
\hline Eggplant & 16 & 15 & 95.4 \\
\hline Watermelons & 90 & 81 & 89.7 \\
\hline Okra & 12 & 11 & 89.0 \\
\hline Limes & 26 & 23 & 86.3 \\
\hline Peppers (not specified) & 82 & 69 & 84.9 \\
\hline Strawberries & 6 & 5 & 83.0 \\
\hline Mangoes & 45 & 37 & 82.0 \\
\hline Onions & 114 & 93 & 81.7 \\
\hline Muskmelons & 145 & 117 & 80.7 \\
\hline \multicolumn{4}{|l|}{ Subtotal, } \\
\hline items $1-15$ & 1,273 & 1,162 & 91.1 \\
\hline $\begin{array}{l}\text { All other fruits } \\
\text { and vegetables }\end{array}$ & 3,942 & 204 & N/A \\
\hline Total & 5,216 & 1,365 & 26.2 \\
\hline \multicolumn{4}{|l|}{ Total, excluding } \\
\hline bananas and plantains & 2.237 & 1.290 & 57.6 \\
\hline
\end{tabular}

${ }^{2}$ Source: "Foreign Agricultural Trade of the United Slates: Calendar Year 1986 Supplement", Washington, D. C., May 1987, USDA

Econ. Res. Serv., Table 25.

Table 5. U.S. annual per-capita consumption of fresh, canned, and frozen fruits and vegetables, 1969-825.

\begin{tabular}{|c|c|c|c|c|c|c|}
\hline \multirow[b]{3}{*}{ Year } & \multicolumn{3}{|c|}{ Fruits $^{y}$} & & & \\
\hline & \multirow[b]{2}{*}{$\begin{array}{c}\text { Fresh } \\
(\mathrm{kg})\end{array}$} & \multirow{2}{*}{$\begin{array}{c}\text { Canned } \\
\text { and dried } \\
(\mathrm{kg})\end{array}$} & \multirow{2}{*}{$\begin{array}{c}\text { Frozen } \\
\text { fruits } \\
\text { and juices } \\
(\mathrm{kg})\end{array}$} & \multicolumn{3}{|c|}{ Vegetables } \\
\hline & & & & $\begin{array}{c}\text { Fresh } \\
(\mathrm{kg})\end{array}$ & $\begin{array}{c}\text { Canned } \\
(\mathrm{kg})\end{array}$ & $\begin{array}{c}\text { Frozen } \\
(\mathrm{kg})\end{array}$ \\
\hline 1969 & 34.9 & 12.3 & 4.4 & 57.8 & 23.4 & 4.1 \\
\hline 1970 & 35.2 & 12.0 & 4.5 & 58.1 & 23.2 & 4.4 \\
\hline 1975 & 37.2 & 10.0 & 6.4 & 62.0 & 23.5 & 4.4 \\
\hline 1980 & 39.4 & 9.1 & 5.9 & 65.3 & 22.0 & 4.7 \\
\hline 1981 & 38.1 & 8.7 & 5.8 & 66.4 & 20.7 & 5.3 \\
\hline 1982 & 38.2 & 7.3 & 6.4 & 69.1 & 20.7 & 4.8 \\
\hline 1983 & 41.6 & 6.9 & 6.8 & 67.3 & 21.4 & 5.0 \\
\hline 1984 & $42.8^{y}$ & & & $74.6^{y}$ & & \\
\hline 1985 & $43.0^{y}$ & & & $75.5^{y}$ & & \\
\hline
\end{tabular}

Source: Agricultural statistics, USDA.

'Fresh fruit consumption per-capita estimates based on an index of 121.6 for 1984 and 122.2 for $1985,1970=100.0$. Fresh vegetable per-capita consumption estimates based on an index of 128.5 for 1984 and 130.0 for $1985,1970=100$.

chandising efforts of the produce industry, the exposure of more and more people from developed countries to other cultures and other cuisines, and increased communication and contacts among peoples. Chinese pea pods (snowpeas), mangoes, avocadoes, kiwi, artichokes, okra, passion fruit, and other tropical and semitropical commodities are now becoming common in family meals in areas of the northern hemisphere where they were hardly known as recently as 25 years ago,

c) Tropical and semitropical horticultural commodities are preferred by the growing ethnic populations who have recently immigrated to the developed countries in the northern hemisphere. West Indians eat various cultivars of yams. Hispanics eat chayote, calabaza, and yuca. Asians enjoy lychee fruit and bok choy. Andean immigrants eat quinoa and oca, etc. These specialized commodities require specialized marketers. There can be no doubt, however, that profitable opportunities are being developed for these products along the southeastern coast of the United States and within the Asian population on the west coast, in enclaves scattered along the Gulf coast, and in inland cities in the midwest.

d) Processed fruits and vegetables, both tropical and temperate, include many horticultural products. The fastest growing items in this category being exported from CBI countries to the United States are frozen temperate vegetables. Frozen broccoli, cauliflower, and okra shipments from CBI countries to the United States were valued at nearly $\$ 12$ million in 1986 , compared to relatively miniscule values in 1980. Concentrated pineapple juice, pickling cucumbers in brine, first-processed hot pepper sauce in barrels, raw spices, tropical fruit concentrates, semi-processed condiments and spices-all are showing increasing sales to the United States and to selected European markets.

e) Cut flowers and ornamental constitute a relatively new category for most of the CBI countries, although some sales have been made from the region for a number of years. The largest sales volume items in 1986 were fresh roses and carnations, together representing imports into the United States of $\$ 2.3$ million. These same two items represented only $\$ 880,000$ in 1983 . This category is expected to grow rapidly in the near term.

f) Another specialized horticultural activity to watch closely is the winter production of certified seed in selected areas of the CBI. This activity requires very specialized and knowledgeable management, but also can bring in very high returns per unit of capital invested when properly managed. 


\section{SOME IMPORTANT PROBLEMS FACING THE HORTICULTURAL INDUSTRY SEEKING OPPORTUNITIES IN THE CBI}

Pests and their control. Everyone should be familiar with the recent problems regarding the Mediterranean fruit fly in the Caribbean Basin region, the former control method using ethylene dibromide (EDB) and the "saga of the mangoes" from the region. The mishandling of the notification, followed by a lack of coordination between the Envrionmental Protection Agency (EPA), the Food and Drug Administration (FDA), the USDA's Animal and Plant Health Inspection Service (APHIS), and the Agricultural Research Service (ARS) of USDA, in attempting to find proved, acceptable alternative treatment methods, will, it is hoped, never be repeated.

Medfly is only one of many serious pests in the CBI region countries that could have negative effects on diversification programs in the area, and/or could become serious threats to producers of fruits and vegetables in the United States (Hartz, 1987). Research is needed to find effect we, acceptable treatment methods that will serve producers in the CBI countries, will help meet rising U. S., or other country, consumer demand for these commodities, and, at the same time, will protect U.S. growers from possible harmful pests.

It also seems logical that additional effort and resources must be applied by the developing countries in the region if they want to expand exports to other countries. They should commit resources to identify accurately populations of harmful pests by regions, to identify and certify pest-free areas through acceptable research, and to engage in acceptable control or eradication programs with the cooperation of U.S. and other knowledgeable experts.

An important aspect that deserves mention is that all of us interested in helping increase marketing efficiency, or working with developing countries on trade and the interdependence in our hemisphere, should help to avoid the erection of artificial trade barriers in the name of "protection and health".

Quality control, grading and standardization. Quality control is one of the most important factors inhibiting growth in horticultural product development in the Latin American countries, It is a byproduct of the shortage of business management skills in many of these countries; it is also partly cultural. In most developing countries, finite quality considerations are of no importance in domestic food marketing systems. Grading 'and standardizing of food products is seldom done formally, and the grades that exist from time to time are extremely variable, based on supply and demand changes, not on objective criteria. It is not uncommon to hear the comment made in Latin America that "the retailer and the housewife grade their fruits and vegetables in the retail end of the channel of distribution". I have investigated produce physical losses in various developing countries. As much as $40 \%$ of the fresh produce harvested never reaches the consumer, and most of this loss is because of poor handling, which shows up at either the retail end of the marketing chain or in consumers' kitchens. Unfortunately, this problem results from a cultural pattern of long standing, and it is extremely difficult to break. The norm is to pack and ship field-run produce of all different qualities, and to handle the produce without proper packaging or care.

Given the heat of the tropics, frequent rough handling, and poor packaging at all stages of the channel of distribution, it is not surprising that the produce reaches the retailer bruised, rotting, and valueless. Breaking these habits with indigenous laborers who are hired to work in packing plants organized to pack fresh produce for export to sophisticated markets and consumers is a most difficult managerial challenge. USAID and its missions have been trying to address this serious constraint by helping provide technical assistance to agribusiness firms, to producers' cooperatives, and to exporters in an effort to teach the need to adopt improved standards of quality and objective grading methods to those standards. The ROCAP Non-traditional Agricultural Export Support Project is addressing this problem as it works with all of the Central American producer and export groups.

Export and import taxes, controls and similar barriers to efficient trade. There are various policies that have been adopted by developing countries, usually in an effort to raise needed revenue, which are often short-sighted vis-à-vis their need to also create jobs, earn needed foreign exchange, and develop export markets. Probably just as frustrating to the entrepreneur attempting to develop an export business is the extensive bureaucracy encountered. Time and rapid delivery are especially crucial factors in a fresh produce export business because of the high degree of perishability of fruits, vegetables, and flowers. This bureaucratic intrusion was the most frustrating factor mentioned by exporters in Honduras at a seminar several years ago. They complained about the very large numbers of papers that had to be signed by too many officials in too many ministries, and required too much wasted time in order to: a) Obtain a license to export a Honduran agricultural commodity; b) obtain a license to import needed supplies, such as paper products or chemicals for a produce packing line; or c) complete paper work to obtain letters of credit or to obtain other credit or financial documents, certifications, etc.

Similarly, clearing products through customs, either outbound or inbound, can be most frustrating; complaints about U.S. customs delays wane to insignificance when compared with actual experiences with customs in many LDCs. These barriers to efficient marketing and trade need to be eliminated. USAID mission are in a good position, along with agricultural and commercial attachés in the U.S. embassies, to help persuade developing country leaders to get rid of these barriers.

Export taxes tend to defeat the purpose of creating more jobs and incomes and earning needed foreign exchange in LDCs because they are regressive. These raise the selling country's product prices above those of nearby competitors and result in lost sales. Similarly, the country that taxes manufactured goods not produced in the LDC but needed as input supplies, raises the cost of growing, processing, or packaging and shipping the product and puts the potential grower and exporter at a competitive disadvantage.

Monetary controls, expatriation of profits and captial. Many developing countries insist that capital and control of enterprises be held by nationals. This means that at least $51 \%$ of the ownership in any enterprise will be provided by indigenous sources, and no more than $49 \%$ can be contributed by foreigners, in this case by North Americans. These arrangements seem to be straightforward, until problems of control of policies, of management, of the distribution of profits and losses, or the distribution of ownership equity are faced. Then, joint capital ventures in developing countries can become quite difficult. Even if a produce specialist or broker from a developed country does not wish to engage in a joint capital venture, but only wishes to enter into a management contract or other type of supply agreement, these factors become important.

A developing country often maintains an overvalued exchange rate on its monetary unit or puts a heavy tax on converting revenues from exports from dollars (or other currencies) to the local currency. Finally, it may restrict the amount of profits that maybe expatriated from the country. In fact, some short-sighted policies prohibit the expatriation of any profits earned in the host country to other countries.

All of these factors, and the various laws in a developing country that might have impact on a produce venture, must be studied carefully by experts before a potential agreement is initiated. Again, consultations with various experts in USAID and the U.S. embassies may be helpful. Newer organizations, such as the Private Sector Relations offices of USAID, in the USDA and in the Dept. of Commerce, all have access to specialists who can give assistance to businessmen. Finally, in the Latin American region, it is fortunate that the Latin American Agribusiness Development Corporation (LAAD) and the Overseas Private Investment Corporation (OPIC) have taken an active role in assisting agribusiness venture in the region over the past 15 years and have developed a great deal of expertise that can be used.

\section{SIGNIFICANT TRENDS-A LOOK AT THE FUTURE}

The growth in volume and value of exports from the $27 \mathrm{CBI}$ countries of Central America and the Caribbean Islands has been 


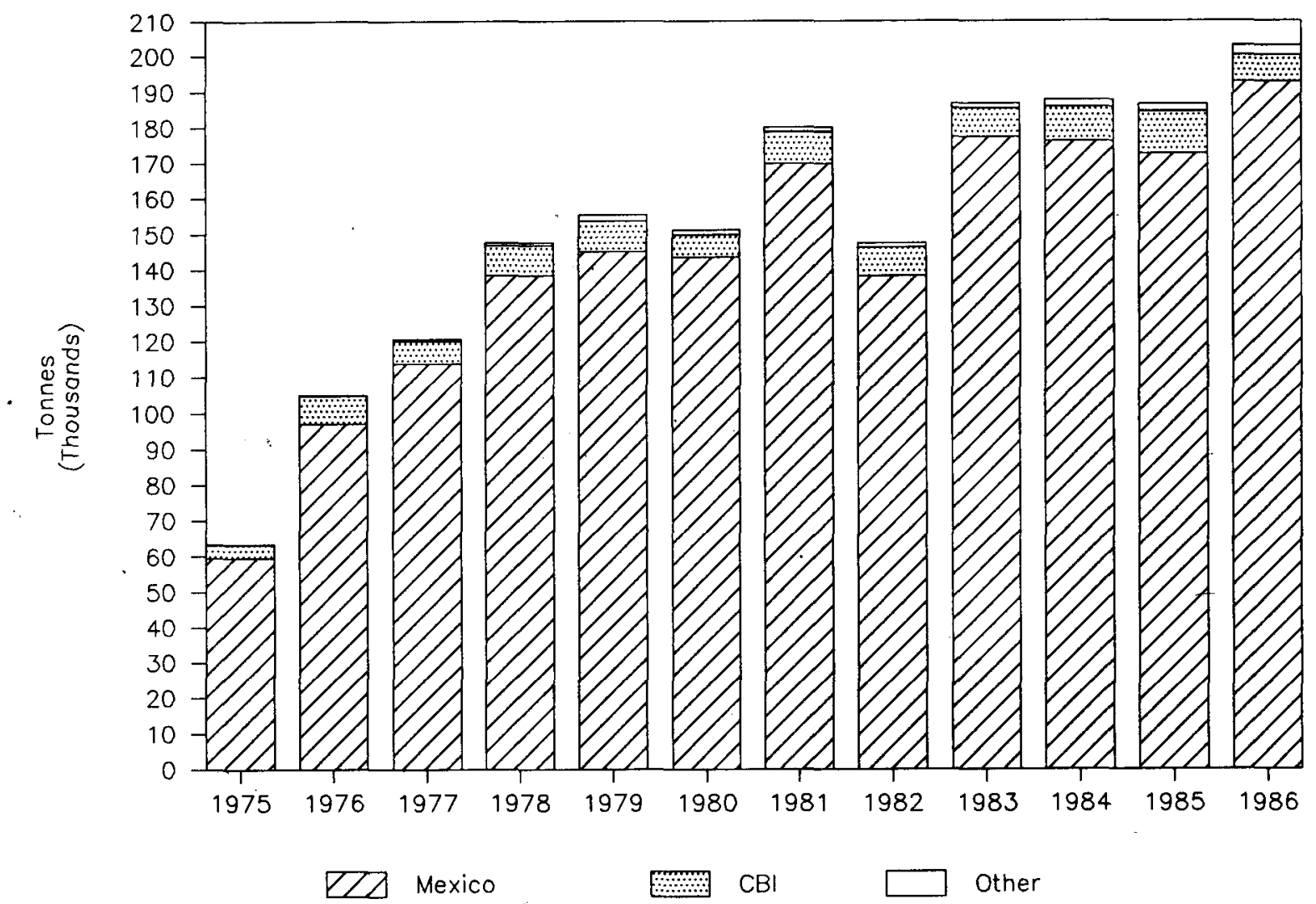

Fig. 1. Twelve-year trends in U.S. imports of cucumbers from Mexico, CBI countries, and all other countries, by calendar year, tonnes. Source: ERS/ USDA, Washington, D. C.

Table 6. Cucumbers: Source of U.S. supplies, production by major states and imports by country of origin, quantity, annual, 1975-86.

\begin{tabular}{|c|c|c|c|c|c|c|c|c|c|c|c|c|}
\hline \multirow{2}{*}{$\begin{array}{c}\text { Source } \\
\text { of } \\
\text { supply }\end{array}$} & \multicolumn{12}{|c|}{ Year } \\
\hline & 1975 & 1976 & 1977 & 1978 & 1979 & 1980 & 1981 & $1982^{z}$ & $1983^{z}$ & $1984^{2}$ & $1985^{x}$ & $1986^{2}$ \\
\hline & \multicolumn{12}{|c|}{ U.S. production $(t ; 1000 s)$} \\
\hline Total & 219 & 230 & 255 & 269 & 269 & 279 & 274 & 272 & 308 & 294 & 311 & \\
\hline California & 33 & 33 & 33 & 33 & 44 & 37 & 38 & 38 & 43 & 41 & 43 & \\
\hline Florida & 84 & 89 & 95 & 107 & 92 & 108 & 103 & 103 & 116 & 111 & 117 & \\
\hline Texas & 19 & . 18 & 37 & 37 & 37 & 37 & 33 & 32 & 37 & 35 & 37 & \\
\hline North Carolina & 17 & 20 & 20 & 19 & 22 & 21 & 21 & 21 & 24 & 23 & 24 & \\
\hline South Carolina & 14 & 20 & 20 & 20 & 19 & 18 & 20 & 20 & 22 & 24 & 22 & \\
\hline \multirow[t]{2}{*}{ Other } & 53 & 51 & 51 & 54 & 56 & 58 & 58 & 58 & 66 & 60 & 66 & \\
\hline & \multicolumn{12}{|c|}{ Imports $^{\mathbf{x}}(t ; 1000 s)$} \\
\hline Total & 59 & 97 & 114 & 138 & 145 & 143 & 170 & 138 & 177 & 176 & 173 & 193 \\
\hline Mexico & 55 & 89 & 107 & 129 & 135 & 136 & 160 & 129 & 168 & 165 & 159 & 183 \\
\hline $\mathrm{CBI}$ & 3.8 & 7.8 & 6.1 & 8.3 & 8.5 & 6.4 & 8.9 & 8.1 & 8.2 & 9.5 & 12 & 7.0 \\
\hline Other & 0.2 & 0.20 & 0.60 & 0.79 & 1.9 & 1.2 & 1.3 & 1.1 & 1.3 & 1.9 & 2.0 & 2.7 \\
\hline
\end{tabular}

${ }^{2}$ Production data from NASS for cucumbers were discontinued after 1981. Numbers for 1982-86 are estimates based on shipment data from the Agr. Mktg.

Serv., USDA.

'Natl. Agr. Stat. Serv., USDA.

${ }^{x}$ U.S. Customs Service.

significant since 1983. As shown in Table 2, nontraditional exports to the United States from the 27 CBI countries grew from $\$ 100$ million to $\$ 215$ million between 1979 and 1986 . The point was made that, while this is a significant trend and an important factor in the economic well-being of the CBI countries, it is relatively insignificant to the United States, which imports nearly $\$ 6.6$ billion of horticultural commodities each year. A second factor of importance to remember is that Mexico alone accounts for $\approx 26 \%$ of the total horticultural products imported into the United States- $\$ 1.72$ billion annually. Excluding bananas and plantains, Mexico accounted for $58 \%$ of all horticultural imports into the United States in 1986 .

The long-term trends in U.S. consumers' demand for fresh fruits and vegetables of all kinds, as well as significant trends in the imports of specific horticultural commodities from the $27 \mathrm{CBI}$ countries, were discussed earlier. Additional insights can be gained by a detailed look at variables for cucumbers, muskmelons, peppers, and mangoes. The data below also show how CBI exports to the United States compare with those from Mexico (USDA, 1978, 1980, 1982, 1984, 1986).

Cucumbers. Imports of cucumbers increased from about 60,000 tin 1975 to 195,000 in 1986 (Fig. 1). Mexico continued to dominate imports, and, in fact, increased its share of total imports from $92.3 \%$ in 1975 to $93.5 \%$ in 1986 . The CBI countries USAID is helping accounted for only $5.3 \%$ of total imports in 1986 .

Some might ask, "Isn't this all at the expense of the American cucumber growers?" The answer is a definite No! Note from the table that, during the period, total production of cucumbers in the 


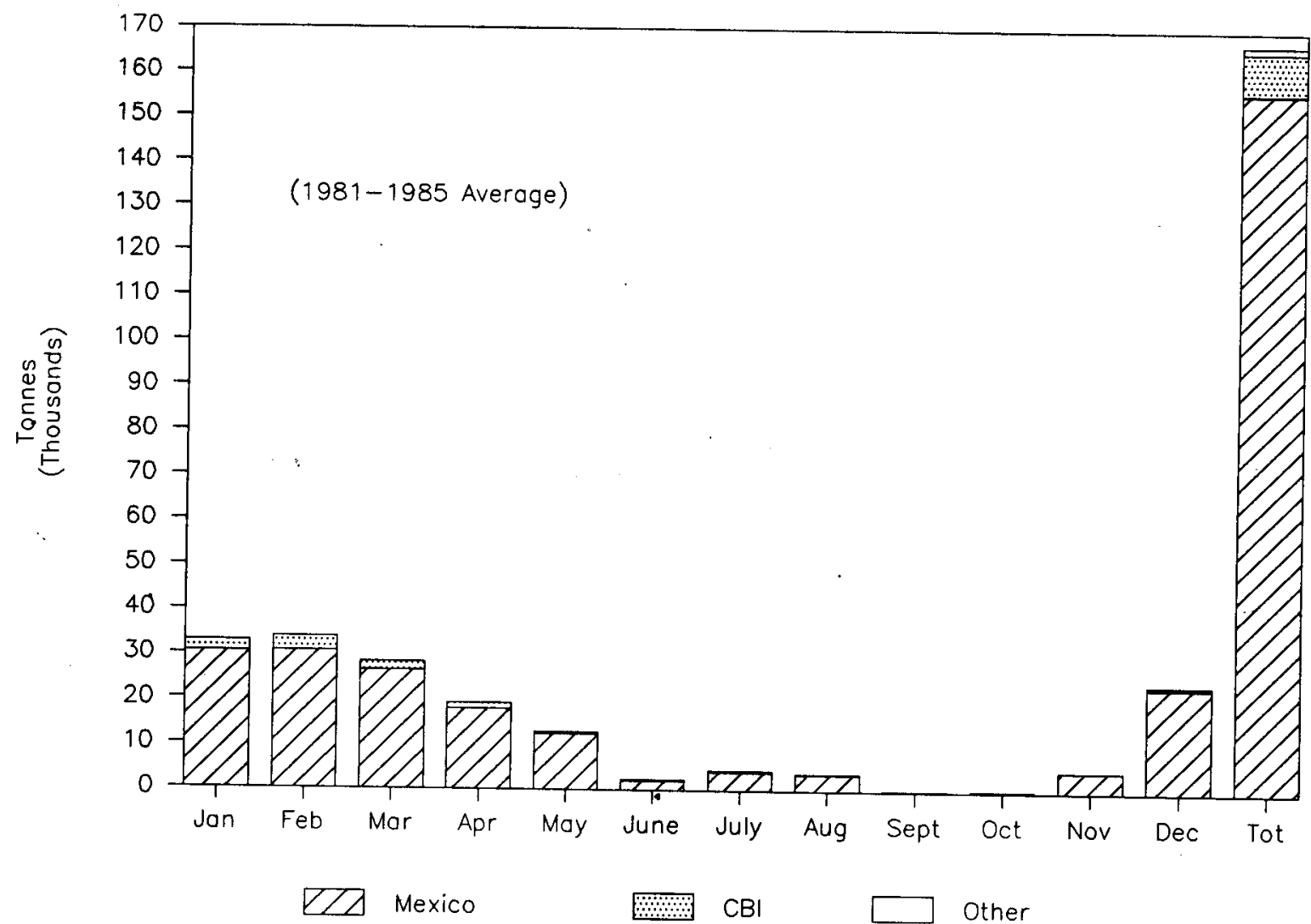

Fig. 2. Seasonality of U.S. imports of cucumbers from Mexico, CBI countries, and all other countries, by month (1981-85 average), tonnes. Source: ERS/USDA, Washington, D.C.

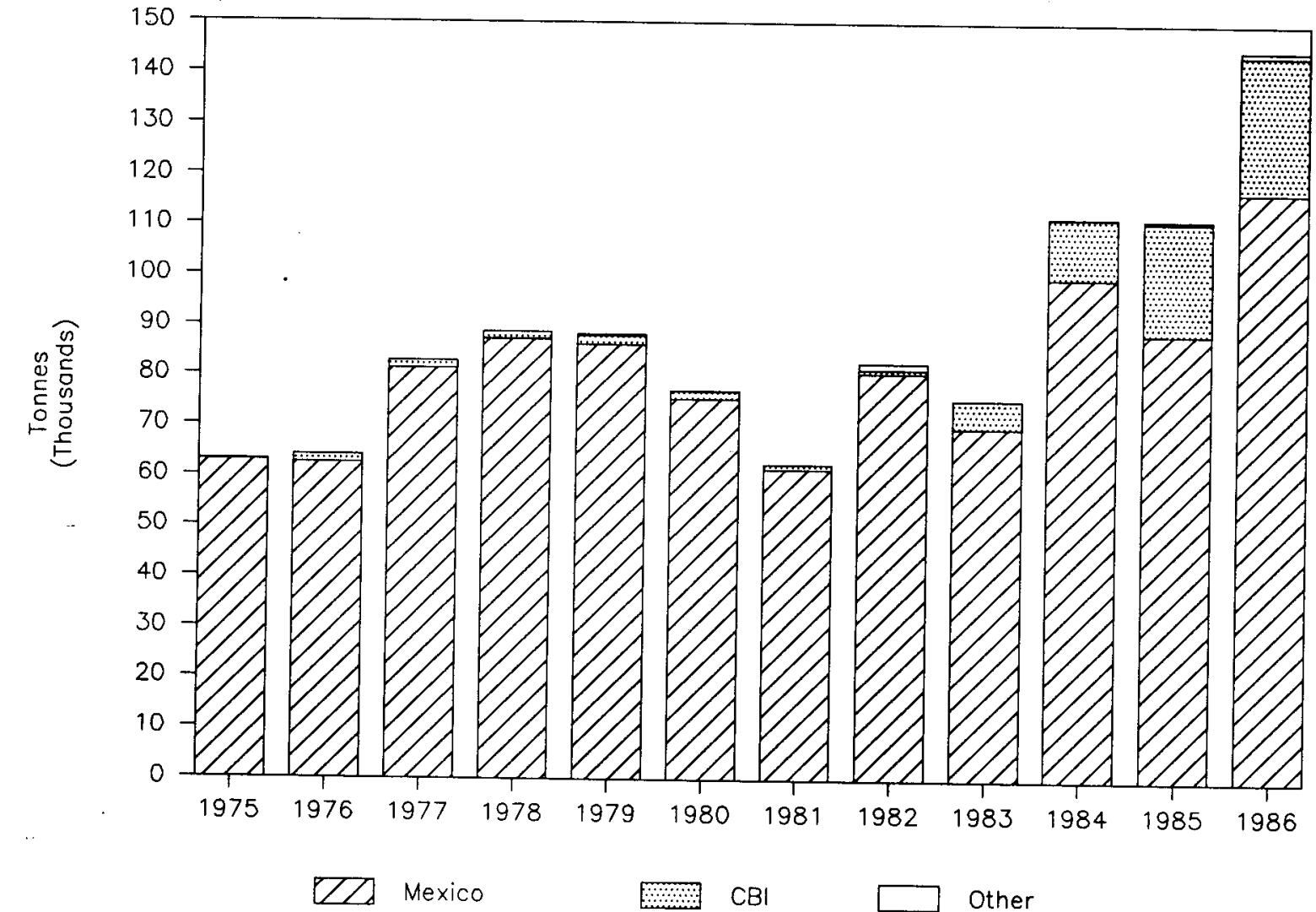

Fig. 3. Twelve-year trends in U.S. imports of muskmelons from Mexico, CBI countries, and all other countries, by calendar year, tonnes. Source: ERS/ USDA, Washington, D.C. 
Table 7. Muskmelons: Source of U.S. supplies, production by major states and imports by country of origin, quantity, annual, 1975-86.

\begin{tabular}{|c|c|c|c|c|c|c|c|c|c|c|c|c|}
\hline \multirow{2}{*}{$\begin{array}{l}\text { Soure } \\
\text { of } \\
\text { supply }\end{array}$} & \multicolumn{12}{|c|}{ Year } \\
\hline & 1975 & 1976 & 1977 & 1978 & 1979 & 1980 & 1981 & $1982^{z}$ & $1983^{2}$ & $1984^{z}$ & $1985^{z}$ & $1986^{2}$ \\
\hline & \multicolumn{12}{|c|}{ United States production ${ }^{y}(t ; 1000 s)$} \\
\hline Total & 447 & 460 & 494 & 604 & 563 & 555 & 605 & 793 & 677 & 687 & 795 & \\
\hline California & 43 & 48 & 72 & 69 & 56 & 41 & 39 & 79 & 67 & 69 & 80 & \\
\hline Florida & 286 & 301 & 283 & 385 & 366 & 383 & 425 & 516 & 440 & 447 & 517 & \\
\hline Texas & 69 & 65 & 92 & 104 & 96 & 92 & 89 & 129 & 110 & 113 & 129 & \\
\hline North Carolina & 15 & 15 & 18 & 17 & 15 & 15 & 18 & 28 & 24 & 24 & 28 & \\
\hline South Carolina & 7.7 & 8.2 & 8.1 & 8.0 & 8.3 & 8.2 & 8.3 & 12 & 10 & 11 & 12 & \\
\hline Other & 26 & 23 & 22 & 22 & 21 & 16 & 26 & 30 & 26 & 25 & 30 & \\
\hline & \multicolumn{12}{|c|}{$\operatorname{Imports}^{\mathrm{x}}(t ; 1000 s)$} \\
\hline Total & 63 & 64 & 83 & 89 & 88 & 77 & 63 & 83 & 75 & 112 & 112 & 145 \\
\hline Mexico & 63 & $63^{\circ}$ & 81 & 87 & 86 & 75 & 62 & 81 & 70 & 100 & 89 & 117 \\
\hline $\mathrm{CBI}$ & 0.07 & 1.4 & 1.6 & 1.4 & 1.8 & 1.5 & 1.0 & 1.0 & 5.6 & 12 & 22 & 27 \\
\hline Other & 0.10 & 0.01 & 0.01 & 0.06 & 0.30 & 0.20 & 0.09 & 1.0 & 0.10 & 0.09 & 0.50 & 1.0 \\
\hline
\end{tabular}

${ }^{2}$ Production data from NASS for muskmelons were discontinued after 1981. Numbers for 1982-86 are estimates based on shipment data from the Agr. Mktg. Serv., USDA.

'Natl. Agr. Stat. Serv., USDA.

${ }^{x}$ U.S. Customs Service.

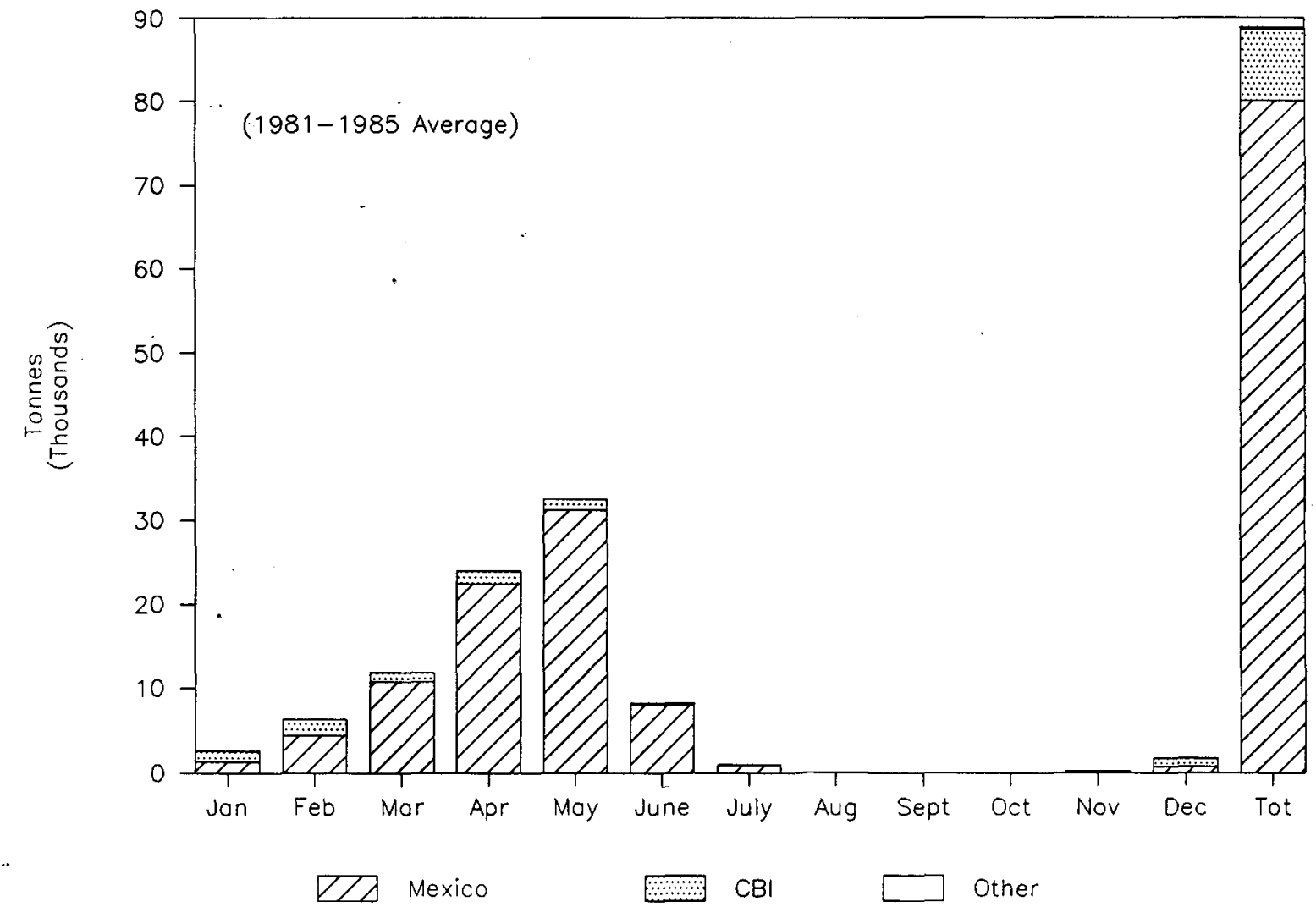

Fig. 4. Seasonality of U.S. imports of muskmelons from Mexico, CBI countries. another countries, month (1981-85 average). tonnes. Source: ERS/ USDA, Washington, D.C.

United States increased from $\approx 219,000$ to 311,000 t per year. Florida's production (Polopalus, 1985) increased from 83,500 $\mathrm{t}$ annually in 1975 to $117,400 \mathrm{t}$ in 1985 . Every other producing state in the United States also showed significant increases in production over the period (Table 6).

The point is that both per-capita and total demand by American consumers continues to grow; both American producers and exporters from Mexico and other countries are benefiting (Houck, 1987). Obviously, most imports occur from December to April, when the "windows of opportunity" are open and when U.S. domestic production and supply are not sufficient to satisfy domestic demand (Fig. 2). The only solution is to make up the difference elsewhere. That is exactly what growers and marketers are doing to keep their produce wholesale and retail customers happy. USAID and the CBI host country institutions are endeavoring to improve the efficiency of these operations in response to the needs.

Muskmelons. A similar pattern to that of cucumbers is demonstrated by muskmelons. Note from Fig. 3 that a steady growth in imports has been seen since 1975 ; i.e., from $\approx 63,000$ to 145,000 $\mathrm{t}$ in 1986. Again Mexico dominated, accounting for $98.7 \%$ of imports in 1975 to $80.2 \%$ in 1986 . The CBI countries have increased their share from $1.2 \%$ of all imports in 1975 to $19.2 \%$ in 1986 . Domestic production also registered large gains: from $\approx 447,000 \tau$ in 1976 to 795,000 in 1985 (Table 7). All major producing states showed significant increases in total production of muskmelons over the period; U.S. demand and consumption continues to grow, and imports from CBI countries are both necessary and desirable to help satisfy the demand when the U.S. climate and producers are not 


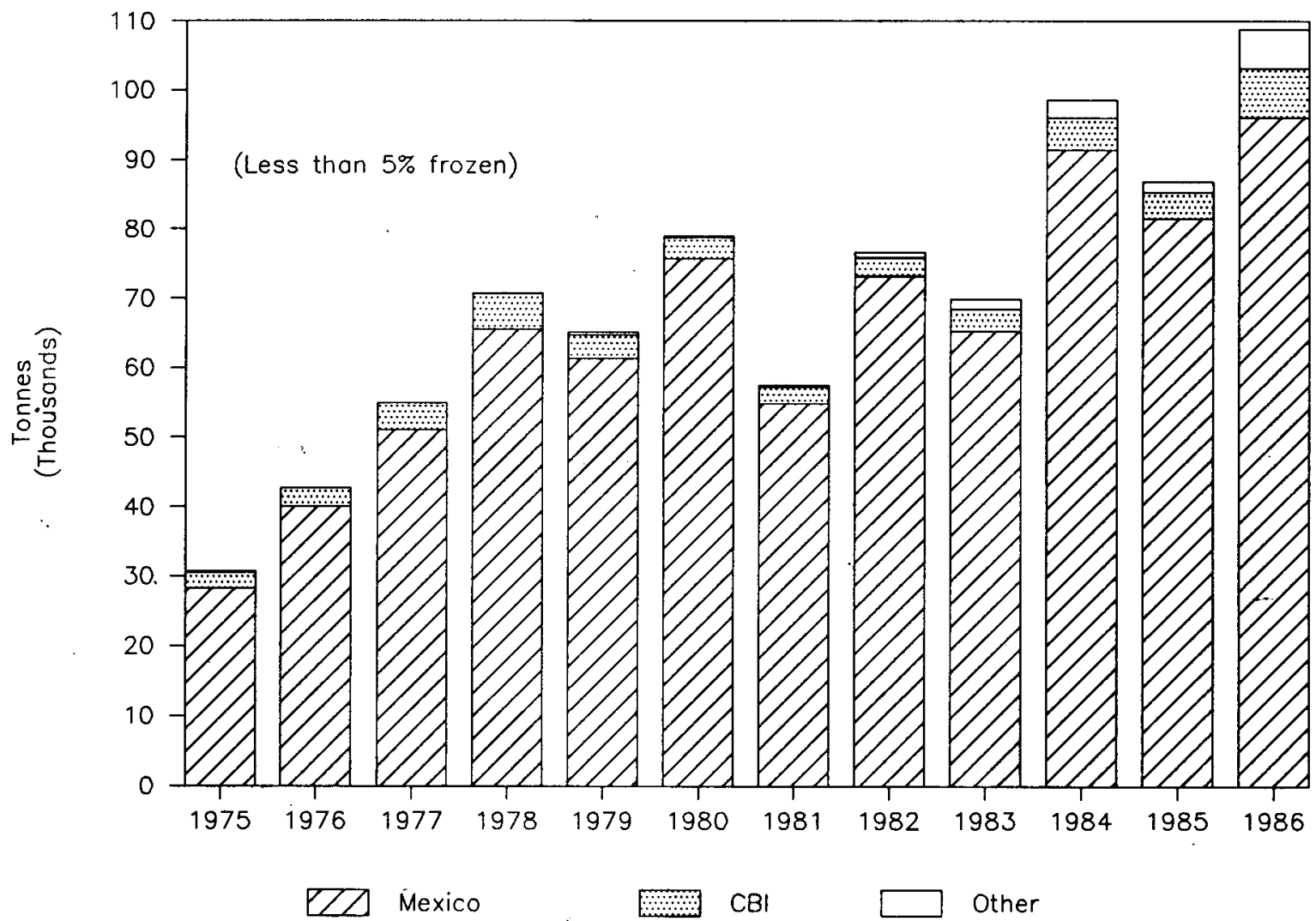

Fig. 5. Twelve-year trends in U.S. imports of peppers from Mexico, CBI countries, and all other countries, by calendar year, tonnes. Source: ERS/USDA, Washington, D.C.

Table 8. Peppers: Source of U.S. supplies, production by major states and imports by country of origin, quantity, annual, 1975-86.

\begin{tabular}{|c|c|c|c|c|c|c|c|c|c|c|c|c|}
\hline \multirow{2}{*}{$\begin{array}{l}\text { Source } \\
\text { of } \\
\text { supply }\end{array}$} & \multicolumn{12}{|c|}{ Year } \\
\hline & 197.5 & 1976 & 1977 & 1978 & 1979 & 1980 & 1981 & $1982^{\prime}$ & $1983^{2}$ & 1984' & 1985' & $19866^{\prime}$ \\
\hline & \multicolumn{12}{|c|}{ United States production $(t ; 1000 s)$} \\
\hline Total & 214 & 238 & 242 & 236 & 264 & 249 & 266 & 294 & 301 & 312 & 305 & \\
\hline California & 68 & 71 & 72 & 69 & 87 & 76 & 79 & 89 & 91 & 94 & 92 & \\
\hline Florida & 86 & 86 & 83 & 86 & 86 & 86 & 91 & 103 & 105 & 109 & 107 & \\
\hline Texas & 25 & 28 & 28 & 29 & 36 & 32 & 38 & 37 & 38 & 39 & 38 & \\
\hline South Carolina & 13 & 13 & 12 & 12 & 12 & 12 & 13 & 15 & 15 & 16 & 15 & \\
\hline New Jersey & 23 & 21 & 24 & 19 & 20 & 22 & 19 & 25 & 26 & 27 & 26 & \\
\hline Other & 16 & 19 & 22 & 21 & 24 & 20 & 27 & 25 & 26 & 27 & 26 & \\
\hline \multicolumn{13}{|c|}{ Imports $^{x}(t ; 1000 s)$} \\
\hline Total & 31 & 43 & 55 & 71 & 65 & 79 & 58 & 77 & 70 & 99 & 87 & 109 \\
\hline Mexico & 28 & 40 & 51 & 66 & 61 & 76 & 55 & 73 & 65 & 91 & 82 & 96 \\
\hline CBI & 2.3 & 2.6 & 3.8 & 5.2 & 3.4 & 3.1 & 2.3 & 2.6 & 3.1 & 4.6 & 3.8 & 7.1 \\
\hline Other & 0.18 & 0.03 & 0.07 & 0.07 & 0.43 & 0.28 & 0.33 & 0.77 & 1.4 & 2.6 & 1.5 & 5.6 \\
\hline
\end{tabular}

${ }^{\text {} P r o d u c t i o n ~ d a t a ~ f r o m ~ N A S S ~ f o r ~ p e p p e r s ~ w e r e ~ d i s c o n t i n u e d ~ a f t e r ~ 1981 . ~ N u m b e r s ~ f o r ~ 1982-86 ~ a r e ~ e s t i m a t e s ~ b a s e d ~ o n ~ s h i p m e n t ~ d a t a ~ f r o m ~ t h e ~ A g r . ~ M k t g . ~}$ Serv., USDA.

${ }^{y}$ Natl; Agr. Stat. Serv., USDA.

${ }^{x}$ U.S. Customs Service. Less than $5 \%$ frozen.

able to do so (Fig. 4).

Peppers. As with the first two commodities, imports of peppers increased from $\approx 30,700$ t in 1975 to nearly 109,000 in 1986 (Fig. 5). Mexico accounted for $93 \%$ of these imports in 1975, and also for $93 \%$ of the much larger quantity in 1986 , while the CBI countries maintained their $6.6 \%$ share. Again, U.S. production grew from $231,600 \mathrm{t}$ in 1975 to $305,000 \mathrm{t}$ in 1985 , with all major U.S. producing states showing large increases (Table 8). Florida, for example, increased total production from 86,100 tin 1975 to 106,800 tin 1985. The winter seasonality pattern of imports of peppers into the United States is similar to that for the commodities discussed above (Fig. 6).

Mangoes. Mangoes area special case, representing anew cornmodity in the typical U.S. consumer's diet. Per-capita consumption is growing very rapidly as Americans become accustomed to this tropical fruit. In fact, U.S. production statistics were not reported by USDA until 1978. Imports have grown from 8100 tin 1975 to 44,700 $\mathrm{t}$ in 1986 (Fig. 7). Total U.S. production is recorded as being produced in Florida, and equaled $4000 \mathrm{t}$ in 1985 (Table 9). Mango production in Hawaii is not reported by USDA, presumably because all of the production is consumed locally. Hawaiian mangoes are not shipped to the contiguous 48 states because of the presence of fruit flies that could be injurious to mainland fruit if introduced. The seasonality of imports is quite different from that of the products discussed above, peaking in the months of June, July, and August (Fig. 8).

In summary, the future picture for horticultural export growth to the United States, to Canada, and to western Europe looks very 


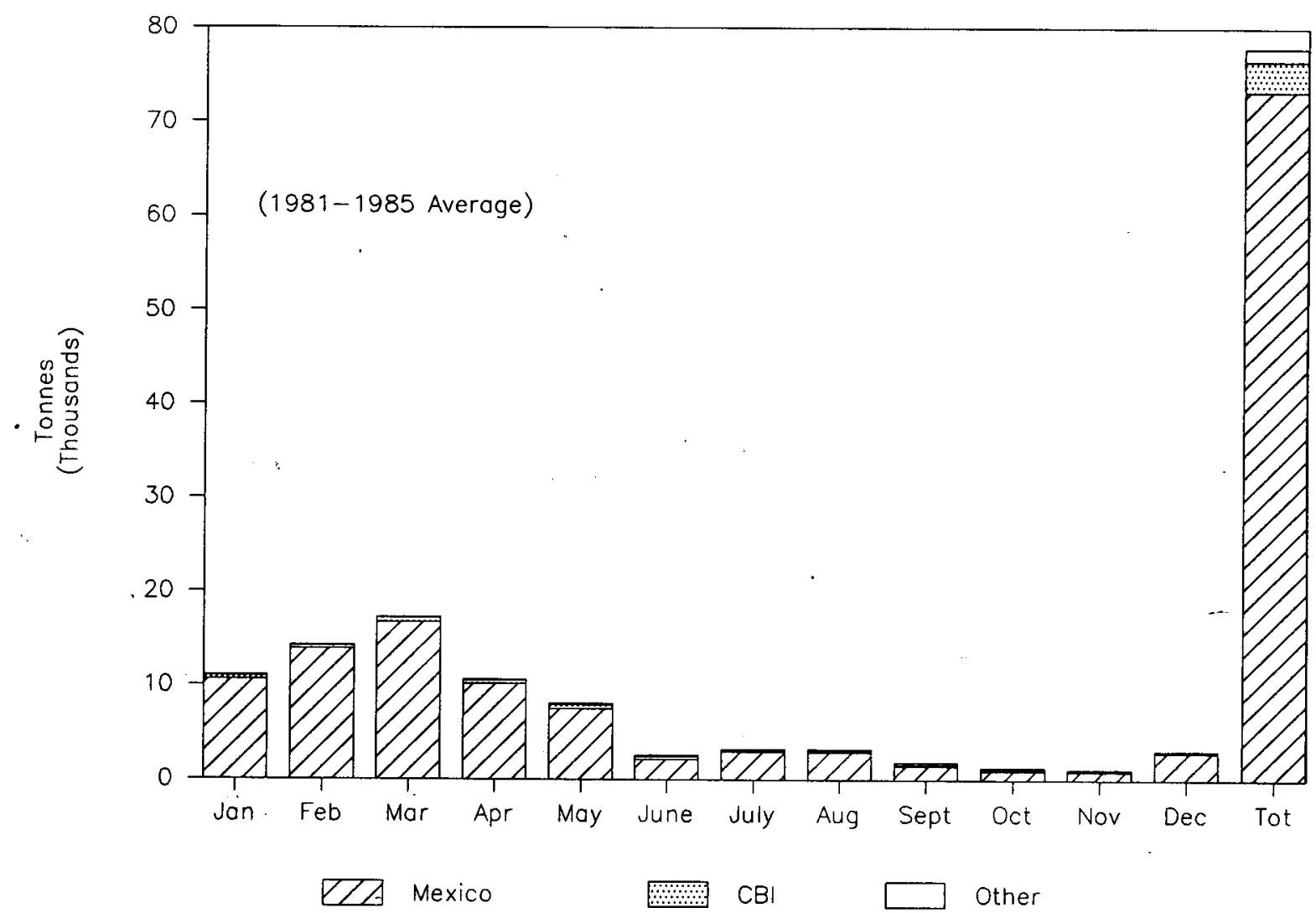

Fig. 6. Seasonality of U.S. imports of peppers from Mexico, CBI countries, and all other countries, by month (1981-85 average), tonnes. Source: ERS/ USDA, Washington, D.C.

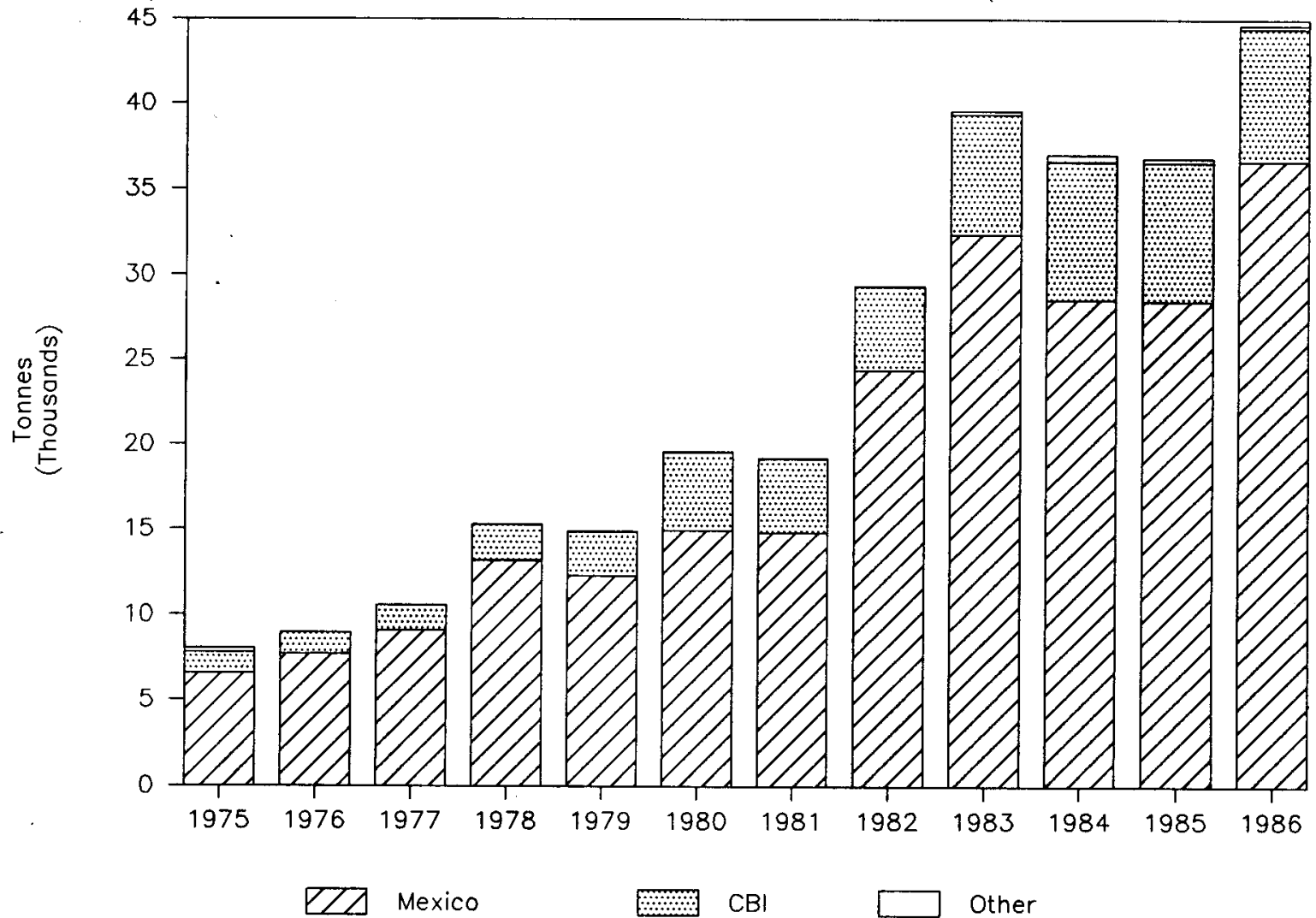

Fig. 7. Twelve-year trends in U.S. imports of mangoes from Mexico, CBI countries, and all other countries, by calendar year, tonnes. Source: ERS/ USDA, Washington, D.C. 
Table 9. Mangoes: Source of U.S. supplies, production by major states and imports by country of origin, quantity, annual, 1975-86.

\begin{tabular}{|c|c|c|c|c|c|c|c|c|c|c|c|c|}
\hline \multirow{2}{*}{$\begin{array}{c}\text { Source } \\
\text { of } \\
\text { supply }\end{array}$} & \multicolumn{12}{|c|}{ Year } \\
\hline & 1975 & 1976 & 1977 & 1978 & 1979 & 1980 & 1981 & 1982 & 1983 & 1984 & 1985 & 1986 \\
\hline & \multicolumn{12}{|c|}{ United States production ${ }^{2}(t ; 1000 s)$} \\
\hline Florida total & 5.2 & 6.4 & 2.9 & 3.8 & 4.3 & $4.0^{\circ}$ & 4.3 & 3.5 & 3.8 & 3.8 & 4.0 & \\
\hline \multicolumn{13}{|c|}{$\operatorname{Imports}^{\mathrm{y}}(t ; 1000 s)$} \\
\hline Total & 8.0 & 9.0 & 11 & 15 & 15 & 20 & 19 & 29 & 40 & 37 & 37 & 45 \\
\hline Mexico & 6.6 & 7.7 & 9.1 & 13 & 12 & 15 & 15 & 24 & 32 & 29 & 28 & 37 \\
\hline CBI & 1.2 & 1.3 & 1.5 & 2.1 & 2.6 & 4.6 & 4.4 & 5.0 & 7.0 & 8.1 & 8.1 & 7.8 \\
\hline Other & 0.30 & $<0.1$ & 0 & 0.03 & 0.03 & 0.04 & 0.03 & 0.06 & 0.20 & 0.40 & 0.30 & 0.20 \\
\hline
\end{tabular}

${ }^{{ }^{7}}$ Fresh market production estimated by ERS from data supplied by Florida Agr. Stat. Serv. and AMS, USDA.

U.S. Customs Service.

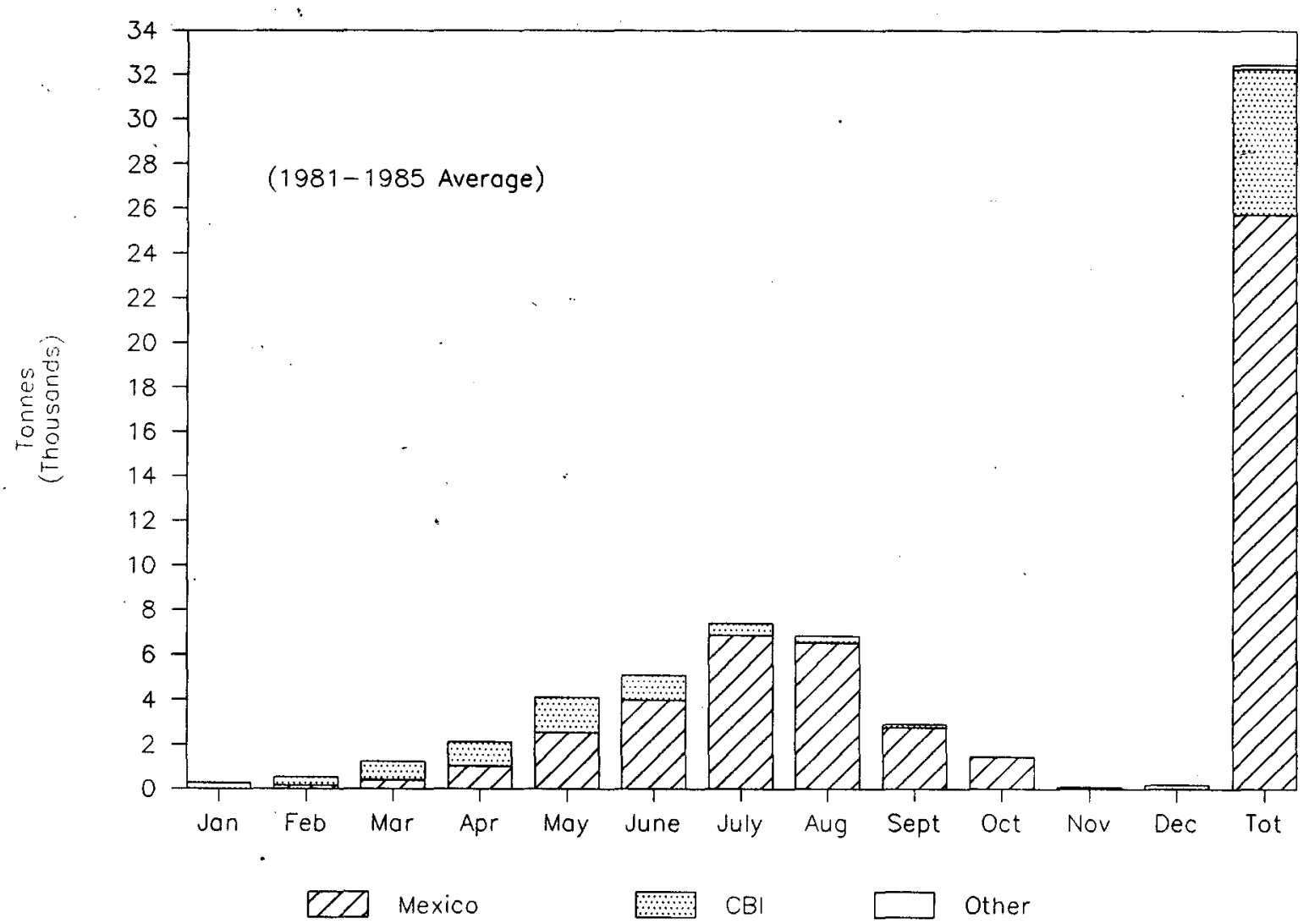

Fig. 8. Seasonality of U.S. imports of mangoes from Mexico, CBI countries, and all other countries, by month (1981-85 average), tonnes. Source: ERS/ USDA, Washington, D.C.

bright for several reasons:

a) Changing tastes and preferences for fresh and frozen fruits and vegetables by consumers will result in significant growth per capita and total demand for "traditional" commodities of this type.

b) Tropical fruits and vegetables that are being eaten by consumers in the developed countries in increasing quantities are becoming increasingly popular in the United States. Included are ethnic foods in demand among our growing immigrant population groups.

c) Tremendous population growth in the southeast and southwest has removed substantial quantities of land from agricultural production. These often were the very areas that previously produced many of our fruits and vegetables, especially in the winter seasons. Now these production areas must be replaced by other areas.

d) Growing per-capita and discretionary incomes permit consumers to travel to other countries and become familiar with other types of cuisines and ambiences, etc., and to purchase "exotic" foods available in hometown stores.

e) Improved handling, packaging, storage, and transportation facilities and methods have permitted more imports from distant production regions.

The major negative points relate to disease and pest control prob- lems, poor management and untrained labor, trade barriers, and the need to provide improved policy and administrative mechanisms, including working capital and credit, to permit timely growing, packing, storage, and transportation of the horticultural commodities at competitive prices.

\section{Literature Cited}

Brown, R., Jr. 1987. Caribbean Basin Initiative stimulates increase in nontraditional exports. Western Hemisphere Situation and Outlook Report. USDA Econ. Res. Ser. 29-31.

Hartz, T. 1987. Will Caribbean Basin Initiative affect you? Amer. Veg. Grower p. 28-29.

Houck, J.P. 1987. Foreign agricultural assistance, it's mostly a good thing for U. S. farmers. Amer. Agr. Econ. Assn., Choices. 2(1):19.

Polopulus, L.C. 1985. The Caribbean Basin Initiative and its potential impact upon agriculture in south Florida. Univ. Florida, Inst. Food and Agr. Sci. Food and Resource Econ. Dept. Staff Paper 295.

United States Agency for International Development. 1978. A. I. D. financing of palm oil, citrus and sugar projects and related products. Policy Determination 71:1.

United States Agency for International Development. 1986. Assistance to support agricultural export development. Policy Determination 15:1-3. 
United States Congress. 1983. Caribbean Basin Economic Recovery Act. P.L. 98-67:Title II.

United States Congress. 1986a. The Bumpers amendment P.L. 99-349: Section 209.
United States Congress. 1986b. Competition with U.S. farm producers. House Rpt. 99-649: Section 209, Amendment 221.

USDA. 1976, 1978,1980,1982, 1984, 1986. Foreign agricultural trade of the United States. Econ. Res. Serv. Table 25.

\title{
Colloquium Summary
}

\author{
L. George Wilson \\ Horticultural Science Department, Box 7609, North Carolina State University, Raleigh, NC 27695-7609
}

"Tropical Horticultural Crop" Development for Export Marketing" has many key participants. The tendency to somewhat oversimplify this subject is understandable because of the prominent roles of the producers, shippers, and marketers. The roles of the various government agencies of exporting and importing countries are also critically important to the success of any multinational operation. Dealing with highly perishable products, such as fruits, vegetables, and flowers, requires a high degree of coordination among participating parties.

Raj Kumar and Campbell have clearly identified many horticultural crops in the tropics that can be exported. Several are already fairly well-known to residents of subtropical and temperate zones and can be further exploited. Several other local favorites have export potential. Exportation for profit depends on proper production and postharvest handling measures to ensure that quality horticultural crops are delivered.

Rinella (see paper by Soule) stressed the critical importance of dealing with transportation issues on long-term and regional scales. Trip by trip, crop by crop, country by country-isolated efforts must ultimately fit into an overall coordinated plan if exporters and importers are to succeed. Private enterprises need to work closely with local government and international funding agencies to resolve complex transportation issues. For example, coordination of production and shipping of perishables from several small countries and consolidation of export and import port facilities would be helpful. Rinella proposes the creation of a fully integrated food handling and transportation system to provide functional links between production areas and market places.

DeFreitas detailed several of the complexities of satisfactorily complying with the many regulations of importing countries. Conscientious efforts are being made to use only those agricultural chemicals registered for use in countries such as the United States. Fair trade agreements are important to the success of producing countries. The development of good relationships with dependable trading partners and brokers is more important in the long run than special arrangements and privileges provided by developed nations. Production of quality horticultural crops is an attainable goal, but quality maintenance during delivery to markets is a real challenge. Reliable transportation is a continuing critical need, underscoring Rinella's plea for an effective, integrated transportation network.

Steele's comments are based on his considerable experience in developmental assistance programs. Although he works with the Office of International Cooperation and Development (OICD) in the U.S. Agency for International Development (USAID), he represents views held by his counterparts in other foreign assistance agencies, such as The World Bank and the Interamerican Development Bank. Steele discussed problems experienced by USAID and their response to them. He described present activities and trends in Caribbean and Latin American missions, with specific examples from the region. Policies affecting bilateral foreign assistance programs of the United States with less-developed countries were discussed.

The outlook of this colloquium was generally optimistic, based on many factors. Consumption of an increasing array of tropical and horticultural products is becoming a part of U.S. tastes and preferences. Pressure on currently productive agricultural lands in temperate zones makes tropical sourcing more feasible. Despite problems identified by some of our colloquium speakers, handling, packaging, storage, and transportation facilities and methods are improving, permitting more imports from distant production regions. Wherever there is an opportunity for a profit to be made in the production and marketing of fresh horticultural crops, entrepreneurs will find ways to deal with barriers and constraints. As horticultural scientists, we will continue to play an important role in the development and delivery of technologies to make "Tropical Horticultural Crop Development for Export Marketing” a reality. 